\title{
From 'warlord' to 'democratic' president: how Charles Taylor won the 1997 Liberian elections
}

\author{
David Harris*
}

\begin{abstract}
A BSTRACT
For the best part of seven years, an increasing number of warring factions fought a vicious civil war for control of the West African state of Liberia. In August i996, the fourteenth peace accord led to presidential and parliamentary elections in July of the following year. Charles Taylor and his National Patriotic Party (NPP), formed out of the original invasion force, emerged victorious with a landslide 75 per cent of the vote. Given the international reputation of Taylor as a brutal warlord whose sole aim had never wavered from the capture of power in Monrovia, Taylor's across-the-board victory appears difficult to explain. Having concluded that, despite problems and allegations, the election did seem more free and fair than not, the article examines the factors that probably influenced the electorate's choices. The results of this research show an election heavily dependent on an uncertain security situation. However, it suggests that, although a former 'warlord' has been rewarded, the voting was a reasoned ploy by the electorate to maximise the possibility of improved living conditions.
\end{abstract}

\section{IN T R O D UGTION}

In several war-torn African states in recent years, competitive multiparty elections have been held as a significant element in the attempted achievement of a negotiated peace. Sometimes, as in Mozambique after the elections of October i 994, this process has been broadly successful; at other times, and most tragically in Angola after those of September I 992, it has merely heralded a return to war. In this context, the Liberian elections of July i 997 stand out as remarkable. Held after seven years of vicious civil war, they were won with a landslide 75 per cent of the popular vote by a candidate, Charles Taylor, with an international reputation as a brutal warlord, to whose lust for power the miseries of the preceding years had often been ascribed. Whereas

\footnotetext{
* David Harris is a Masters graduate from the School of Oriental and African Studies and works as the Resource and Information Officer at the Africa Centre, London. The author would like to acknowledge the inspiration and assistance he has received in writing this article, particularly from Dr Richard Jeffries and Dr Max Sesay.
} 
other such post-conflict elections had, to a greater or lesser degree, served to reinforce the backing which each of the previously conflicting parties received from the regions of its main ethnic support, Taylor despite substantial ethnic and regional variation - was able to gain over half of the vote in every single county of Liberia. It is this outcome that this article seeks to explain.

BAGKGROUND TO THE ELEGTION AND THE POLITIGAL ACTORS

OF I 997

The Liberian elections were heavily influenced by the actions of prominent players with long histories of involvement in Liberian politics. It is with this in mind that an outline of pre-election political history is necessary. Despite its declaration of independence in I847, Liberia only began to emerge from the political and economic dominance of Americo-Liberians, the descendants of freed slaves mainly from the Americas, during the presidency of William Tubman ( I 944-7I). His successor, William Tolbert, continued many of Tubman's policies, including the promotion of Africans such as current luminaries Togba-Nah Tipoteh, an ethnic Kru, Ellen JohnsonSirleaf of mixed ancestry, and George Boley, a Krahn, into governmental positions (Tipoteh I98I: 4; Osaghae r996: 63). ${ }^{1}$ However, he faced a difficult tenure. The oil crisis and the downturn in primary commodity prices soon exposed the export-dependent economy and government reliance on patronage. A $5^{0}$ per cent increase in the price of rice precipitated riots, which were violently put down, in April r979. During this time, the Movement for Justice in Africa (MOJA), of Henry Fahnbulleh and Tipoteh, and the Progressive Alliance of Liberians (PAL), of Baccus Matthews, came to the fore. Matthews was arrested for organising the banned demonstration that had led to the riots. Two days short of a year after the riots, Tolbert's exposed True Whig Party (TWP) government fell to a coup of African non-commissioned officers.

Out of the initially very popular military takeover emerged the People's Redemption Council (PRG), led by Master-Sergeant Samuel Doe. This administration, desperately short of qualified personnel, embraced other former opposition to the TWP and boasted several civilian ministers, including Matthews, Fahnbulleh and Tipoteh. Charles Taylor took over the General Services Agency (GSA), charged with procurement and allocation of government properties. 
The coalition, however, was not to last. Civilian elements were soon replaced with former TWP stalwarts, such as Boley and Jackson Doe (no relation), despite the fact that Samuel Doe had started his regime with the killing of Tolbert and public execution of twelve members of his government. At the same time, the composition of the PRG became more and more inclined towards Doe's ethnic Krahns, despite the fact that these numbered only 5 per cent of all Liberians. Important to later events, Krahn domination of the military and government was accompanied by an expansion of Mandingo commercial and governmental ties. Mandingos, still regarded as outsiders or economic exploiters in many parts of Liberia, came to dominate commerce during the ig8os, including owning or operating as much as 90 per cent of the transportation network (Konneh i996: i 38). The battered economy continued to shrink under corruption and mismanagement (Osaghae i 996: 76), and the regime began to reveal its predatory side. Under pressure from his main backer, the USA, and from within, Doe was forced into elections, set for October i 985.

Doe and his newly formed National Democratic Party of Liberia (NDPL) emerged victorious from the 1985 elections after eliminating major opponents from contention and flagrantly rigging the count. Doe was 'elected' with $5^{\circ} 9$ per cent of the vote, but it is reckoned by most that he actually achieved about half of this (Clapham ig89: io6; Berkeley i 986: I i 7). Jackson Doe, a Gio from Nimba County, was widely acknowledged as the real winner. The United People's Party (UPP, formerly PAL) and the Liberian People's Party (LPP, formerly MOJA), the two parties with pre-coup histories and mass followings, were banned, along with Matthews, for espousal of 'foreign ideologies' (Liebenow i987: 288). Johnson-Sirleaf, having announced her intention to stand as senatorial candidate, served two periods of detention, one before and one after the election, before fleeing the country (Berkeley I986: I03-4). In the immediate aftermath of the election, Doe's former collaborator in the ig8o coup, Thomas Quiwonkpa, another Gio, died in a thwarted coup attempt. Doe's subsequent purge of the army and attacks on Gio (and also related Mano) civilians were swift.

In the meantime, Taylor had fled Liberia and seen the inside of a US prison for the charge of embezzling $\mathrm{L} \$ 900,000$ at the GSA, but had escaped two months before the Quiwonkpa coup attempt. ${ }^{2}$ In his investigation, Mark Huband ( 1998: i 8-22) concludes that Taylor was probably guilty of embezzling at least some of this money, and describes him running the GSA like a fiefdom. However, he played no 
part in the coup, but began to accumulate backing from AmericoLiberians in the USA, where he had spent most of his life, and from Libya through the Burkinabé leader, Blaise Compaoré. Taylor's invasion into Nimba County in I989 was launched from another sympathetic country, Côte d'Ivoire, with a significantly non-Liberian force, only about 200 strong. ${ }^{3}$ As an Americo-Liberian with little connection to the hinterland, Taylor was substantially aided by Doe's overreaction and targeting of Gio and Mano civilians. A Mandingo call to arms to defend and finance the government, made by the information minister, Alhaji Kromah (Ellis I995: I82), may also have worked to Taylor's advantage. Gios and Manos subsequently flocked to Taylor's National Patriotic Front of Liberia (NPFL), and Krahns and Mandingos became targets themselves. In his history of the Gola in Liberia, Warren d'Azevedo ( I970-1 : 8-9) warns that ethnicity holds a 'high degree of flexibility and option for both individuals and groups', and goes on to stress its role as 'an instrument of opportunistic manipulation'. His observations continue to have resonance today.

Despite an early split in the NPFL, Taylor quickly attracted multiethnic support generated by a hatred of Doe and those seen as his supporters. Beyond the brutality of the Doe regime, many had lived with unemployment and a huge wealth gap, particularly visible around the foreign-controlled concession areas. By mid-ı990, Taylor's forces held over 95 per cent of the country, with Doe and breakaway rebel leader, Prince Johnson, controlling only parts of the capital, Monrovia. During the stand-off, the first troops of the Economic Community of West African States Monitoring Group (ECOMOG) 'peacekeeping' mission arrived and almost immediately engaged in military action against Taylor. The systematic and ethnically motivated violence of both the NPFL and Doe's Armed Forces of Liberia (AFL) during this period is well documented (Africa Watch ig9oa, b; i99I; LCHR I99I), as is Taylor's targeting of nationals from ECOMOG countries (Brehun I99I; Ogunleye I995). A visual reminder of the violence was widely circulated in the form of a video of Doe's torture and death at the hands of Johnson in September i99o.

A period of stalemate lasted into i 992. ECOMOG propped up an Interim Government of National Unity (IGNU), led by academic and MOJA member Amos Sawyer, which included Matthews and Fahnbulleh amongst others. At the same time, Taylor constructed a commercial empire in his grandly titled 'Greater Liberia', which, at its height, included virtually all of Liberia and parts of Guinea and Sierra Leone. Taylor's 'state' boasted its own currency, TV, radio, 
newspaper, international airport and deepwater port. The export trade in rubber, gold and diamonds boomed and, by i99I, Taylor had become France's third largest source of tropical hardwood (Reno I 993 : I80). A US official estimated that Taylor may have had access to US $\$ 75$ million per year (West Africa, 8 July, I996). ${ }^{4}$ Gbarnga, the capital of 'Greater Liberia', became the seat of the National Patriotic Reconstruction Assembly Government, complete with ministries and banks.

Peace conferences came and went to little effect, and any hope of stability was rudely shattered by the emergence of the anti-Taylor United Liberation Movement of Liberia (ULIMO), which began to make inroads into diamond-rich western Liberia in late i99I. From I 992 onwards, large parts of Liberia became contested regions in a fracturing factional arena. The misnamed Liberian Peace Council (LPG) emerged in south-eastern Liberia in late I993 under the leadership of Boley with a mainly Krahn membership and alleged ECOMOG backing (Reno I 996b: 2 I4). ULIMO split in early I 994 between its Krahn and Mandingo components, led by Kromah (ULIMO-K) and Roosevelt Johnson (ULIMO-J), respectively. In mid-I994, an alliance of breakaway NPFL senior officials and ULIMO-J, ECOMOG and LPC forces was successful enough to overrun Gbarnga for a short period. The proliferation of warring parties can be readily explained by the commercial possibilities on offer and the increasing probability of recognition at peace talks. The descent of the war into a spiral of indiscriminate violence and looting has, though, encouraged observers to seek deeper explanations. Unpaid, traumatised youth became obedient and loyal fighters; and unfed troops, in the absence of strong leadership or ideology, resorted to looting and terror. Again, these abuses are well documented (HRW/A r 994a; Africa Watch r 99 I). Further, Steven Ellis ( I 995) has endeavoured to put the more grotesque and bizarre elements of the war, such as the incidence of ritual cannibalism and transvestism, into perspective by highlighting the misuse of the sometimes violent rituals of Poro and Sande secret societies, prevalent among most of Liberia's ethnic groups.

Signed in the Nigerian capital in August 1995, the first Abuja Accord made real the two-year old Liberian National Transitional Government (LNTG), significantly, the first administration to include warring faction leaders in its hierarchy, and Taylor made his longawaited return to Monrovia. The head of the LNTG, Wilton Sankawulo, proved unable or unwilling, however, to check the growing 
authority of the faction leaders, and an outbreak of violence and looting erupted on the streets of Monrovia in April i 996. By this point the war had probably claimed the lives of between I 50,000 and 250,000 people, and made over half of Liberia's estimated $2 \cdot 7$ million population refugees or internally displaced. ${ }^{5}$

The second Abuja Accord, signed almost exactly a year after the first, adopted another civilian, Ruth Sando Perry, as head of the transitional government. It is unlikely, though, that the arrival of a determined Perry and a new, ebullient commander for the ECOMOG forces, Major-General Victor Malu, were the only factors that tipped the balance towards peace. The enmity that had existed between Taylor and the Nigerian leader, Ibrahim Babangida, was not carried over to Babangida's successor, Sani Abacha. From the time of the first Abuja conference, Abacha clearly saw Taylor as the only means to end a costly intervention and allow Nigeria to emerge as the champion of Liberian peace and democracy, a very useful image to counter the many negative ones concerning the Abacha regime. ${ }^{6}$ With evidence emerging of Taylor-ECOMOG business deals (Reno I 996b: 2 I 5), the commercial interests of both parties would also be satisfied.

Abuja II, as it became known, laid out the timetable for disarmament and demobilisation of forces (3 I January i997, later extended by a week), and the establishment of the Independent Electoral Commission (IECOM) to administer the registration of voters and the election process. The date of the polls was set for 30 May i997, but was subsequently postponed to I 9 July when the timetable was found to be far too exacting. Due to the displacement of hundreds of thousands of people, it was decided to administer one election using country-wide proportional representation to elect the president and to allocate legislative seats. Polls, however, would not take place in refugee camps in neighbouring countries. The Io,ooo strong ECOMOG force would remain to provide security arrangements across the entire country. Many potentially disruptive problems, such as the almost successful 3 I October assassination attempt on Taylor's life (West Africa, i 8 Nov., I997) and the very late disarmament, did not prove terminal. The elections proceeded on the revised date, giving Taylor $75^{\circ} 3$ per cent of the vote and the NPP 49 of 64 seats in the House of Representatives and 2 I of 26 seats in the Senate (Table I). The Unity Party (UP) and the All Liberia Coalition Party (ALCOP), which came second and third, were the only other parties to be represented in both the House and the Senate. The Alliance, the UPP and the LPP gained seats in the House alone. 
TABLE I

Parties and Candidates in order of appearance on the ballot papers in I 997

\begin{tabular}{lll}
\hline \hline Party & & \multicolumn{1}{c}{ Candidate } \\
\hline PPP & (Progressive People's Party) & Chea Cheapoo \\
NRP & (National Reformation Party) & Martin Sherif \\
FDP & (Free Democratic Party) & Dr George Toe Washington \\
LINU & (Liberia National Union) & Dr Harry Moniba \\
UP & (Unity Party) & Ellen Johnson-Sirleaf \\
ALCOP & (All Liberian Coalition Party) & Alhaji GV Kromah \\
NPP & (National Patriotic Party) & Charles Ghankay Taylor \\
Alliance & & Cletus Wotorson \\
RAP & (Reformation Alliance Party) & Dr Henry Boima Fahnbulleh \\
PDPL & (People's Democratic Party of Liberia) & Fayah Sahr Gbolie \\
UPP & (United People's Party) & Gabriel Baccus Matthews \\
NDPL & (National Democratic Party of Liberia) & Dr George Boley \\
LPP & (Liberian People's Party) & Dr Togba-Nah Tipoteh \\
\hline \hline
\end{tabular}

\section{FREE AND FAIR ELEGTIONS?}

\section{What the observers saw}

The Liberian elections were scrutinised by around 500 international observers. Foreign institutions included the Organisation of African Unity, the United Nations (UN), the Carter Center, the European Union (EU) and the Friends of Liberia (FOL), alongside a coalition of domestic organisations, the Liberian Elections Observation Network (LEON). The extent of the activities, however, varied from organisation to organisation. The EU/Japan contingent comprised 57 members and did not arrive in the country until i 7 July. In contrast, the smaller 34-member FOL team observed the whole of the registration process, the campaign and the polls. The UN put 34 medium-term and 200 short-term observers in the field, covering I, 500 of the I,864 polling sites on the day. LEON deployed I, 200 observers, but only on election day. It is worth noting that the larger teams visited most counties on polling day, with the exceptions of the sparsely populated eastern counties of Maryland and Grand Kru, which were made extremely difficult to access by the rains. On top of all this, the vast majority of polling places were monitored by multiple political party observers.

All of the major groups, on the whole, concurred with FOL ( I997b) when they announced that, 'despite problems, this process was free, fair 
and transparent'. Indeed, Jimmy Carter declared 'a uniformly excellent election process' reported by his forty observers (Carter Center I 997) and the UN announced that they had received no reports of violence, intimidation or major irregularities (UNSG 1997). Most teams, however, noted the unlevel playing field on which the elections were conducted. As long time controller of a large slice of the country and with immense resources at his disposal, Taylor can be seen as playing the role of de facto incumbent in this election. Considering that illiteracy was estimated at 6i per cent even at the start of the war (World Bank i995), that newspapers barely circulated beyond the capital, and that television stations were not operable, Taylor's KissFM radio station was singled out as a major advantage. Kiss-FM and its sister station, Radio Liberia International, were the only Liberian short-wave stations, until a few days before the election, to reach far beyond Monrovia or to play throughout the night. ${ }^{7}$ Kevin George of FOL (I997a) poignantly observed that many people heard about the election only through occasional BBC or Voice of America stories and NPP radio. The British report noted that 'most parties attracted attention to their presidential candidates but lacked the finance or organisation for effective campaigning' (FCO I997). In contrast, Tshirts and bags of rice flowed freely from NPP stocks. Other frequently mentioned anomalies or deficiencies included the lack of voter education, the proximity of voters to ECOMOG soldiers who were none the less praised as impartial, and the inadequate voter registration. Registration was of particular concern, considering an extremely short timetable of only seven days (extended to two weeks in some areas) in the middle of the rainy season. Another factor was the disenfranchisement of between 400,000 and 650,000 refugees outside Liberia. ${ }^{8}$ The general underfunding of IECOM and the timetable, described as 'uncomfortably tight' by UN secretary-general, Kofi Annan (IRINWA, 29 June I997), were criticised. Most importantly, though, all concluded that none of the problems were serious enough to have significantly altered the result.

Were the observers looking in the right direction?

Vociferous accusations were made by several of the defeated candidates, though Cletus Wotorson of the fourth-placed Alliance accepted the 'free and open elections', adding that he didn't need 'a job from Mr. Taylor to survive' (Daily Observer, Monrovia, 24 July I997), and 
Matthews acknowledged 'the will of the people' (The Post, Monrovia, 28 July i 997). The most vocal cries came from UP and ALCOP, but these parties, in the end, acquiesced in the results. Sirleaf-Johnson of the UP announced that they would file a protest for the records but would not pursue it, ${ }^{9}$ while Kromah accepted defeat, ostensibly in the name of peace.

Complaints, mostly concerning NPP rigging or cheating in some form, were made in the press by the UP, ALCOP, Boley's NDPL (the party created by Doe) and Fahnbulleh's RAP. The UP and the UPP could point to clear evidence of NPP intimidation in Nimba County early in the campaign period (The Inquirer, Monrovia, 2 I June i 997). Taylor was accused on many occasions of exceeding the US\$3.5 million official spending limit. The appearance of at least one campaign helicopter and many generous 'gifts', such as the US\$23,00o to airlift the national football team to a match in Togo (National Chronicle, Monrovia, I 7 July i 997) would seem to substantiate this. Registration brought out its fair share of suspicions. Several witnesses reported minors as registering unhindered, ${ }^{10}$ and a communiqué signed by all parties, except the NPP, alleged registration irregularities and the selling of voter cards. At the polls, Johnson-Sirleaf stated that ECOMOG soldiers had voted or told people how to vote (IRIN-WA, 2 I July I997), and the donation of US\$I million to IECOM by the Taylor-friendly government of Taiwan was seen by some as indicative of IECOM bias. Allegations were made that counts of zero were registered for both Boley and George Toe Washington at the very polling stations in which they had cast their own votes (Daily Observer, 28 July i 997), and the UP claimed that party representatives had been under duress to sign the tally sheets at the polling stations (The Inquirer, 23 July i997). Almost inevitably, rumours of deeper conspiracies abounded, often involving Abacha and Libyan interests, ${ }^{11}$ but to the knowledge of this author no evidence to substantiate these has yet emerged.

\section{Conclusion}

Richard Jeffries (I998: I89) argues that 'very limited acceptance of election results, however justified or unjustified, is almost bound to obtain in economically underdeveloped African societies where, partly for structural and partly for cultural reasons, politics continues to be very much a zero-sum game characterised by high levels of distrust'. Certainly, the legitimacy of many an election won by an incumbent in 
nineties Africa has been challenged by the defeated opposition. The key question in each case is whether the defeated parties have sufficient grounds for a grievance, or whether the 'high levels of distrust' have created a pattern of non-acceptance that is difficult to avoid. If we accept that there will be some malpractice, the difficulty is judging whether its existence has critically affected the outcome, or indeed, whether allegations have just been the result of procedural inadequacies, particularly in a rapidly organised election.

There is no doubt that, despite agreement on the electoral rules by all parties, certain rules played into Taylor's hands. The short and chaotic registration period and the compressed electoral timetable most likely benefited the NPP, with its better organisation and established structures, more than the other parties. Victor Tanner (I998: I39) notes that only an estimated 29 per cent of the total population registered in urban Montserrado, in comparison to $5^{\circ}$ per cent and $5^{\mathrm{I}}$ per cent in the NPP strongholds of Bong and Nimba Counties. All opposition to the NPP had very limited preparation time, especially in areas that were only made secure very late in the day. Taylor was eager to avoid a further postponement of the election date and made his thoughts known in a thinly veiled attack on the head of IECOM. ${ }^{12}$ The impact of the absence from the poll of probably half a million refugees is extremely difficult to judge when even the total estimates differ so wildly. Even though this represents some 250,00o voters (compared to the 622,000 who took part), and many of those who fled and did not return were probably those who found Taylor's rule particularly hard to bear, it certainly could not be concluded that all of the refugees, coming from different parts of the country, would have voted against Taylor or that their exclusion was a Taylor-inspired rule. Logistics, expense, the desire to complete an election sooner rather than later, and the reluctance of Guinea and Côte d'Ivoire to allow voting in the camps, were more likely factors that excluded the refugee population that was unwilling or unable to return. An interesting point made by Terrence Lyons ( I999: 6o) concerns the single ballot rule. This may have favoured Taylor in that it removed the possibility of, for instance, voting Taylor for president and a rival party for the legislature. Alex Vines (I 996: I 59) suggests that this balancing or tactical voting was a significant factor in the I 994 post-conflict Mozambican elections.

Despite the fact that NPP resources could take their message much further afield, with greater inducements and a certain amount of intimidation, this cannot indubitably be presented as a decisive factor. First, there is the fact that such obstacles have been surmounted in 
several other African countries, such as Zambia, Malawi and twice in Benin. In Ghana in r 996, Jeffries ( I998: 200-4) acknowledges the imbalance in media coverage and financial resources, but suggests:

to attribute very much influence to this factor would seem to depend on making a series of highly questionable, and in some cases quite patronising, assumptions regarding the levels of political information possessed by rural voters, the determinants of their electoral behaviour and the persuasive potential of a better resourced [opposition].

In Montserrado, where the electorate had relatively easy access to opposition campaigns and media, Taylor still polled a handy 55 per cent. Most importantly, the unlevel playing field had, effectively, been overcome in Liberia on a previous occasion. In the I 985 election, Doe employed the extensive use of government funds and media, never mind the banning of political parties, the incarceration of politicians, harassment of civil servants and state violence towards the electorate. He had still, however, to resort to a secret and almost certainly fraudulent count by a hand-picked committee to secure victory. By most accounts, the Liberian electorate had chosen an opposition candidate against the tide of an incumbent advantage far greater than Taylor's.

It is also likely that some irregularities marred the registration, the campaign and the voting, judging by the quantity of allegations, even if few of these are corroborated. There are certainly reasons why Tom Ikimi, the Nigerian foreign minister, who exercised a great deal of control over the running of the elections, should wish for a swift Taylor victory. ECOMOG-NPP connivance and IECOM weaknesses would have opened the door to attempts to defraud the process. ECOMOG soldiers' close proximity to polling booths and voters was not a desirable electoral arrangement. It is clear, however, that Ikimi and Malu were also keen to minimise overt irregularities, in order to present a clean election to the world. Malu's response to blatant NPP intimidation was unequivocal, and had the desired effect of removing that form of organised violence from the streets. ${ }^{13}$ It would appear that Taylor was also anxious to win in an apparently legitimate poll. Even though Taylor still effectively controlled central Liberia, there is little evidence to suggest that irregularities were all centrally inspired by the NPP. Many could equally be local opportunism or deficiencies in the system, for instance the sale of voter cards and the registration of minors. FOL (I997c), who observed the entire process, concluded that it did not detect any 'pattern of fraud, intimidation or manipulation'.

Important to note is the near absence of certain types of irregularity. 
The campaign was marred by relatively little violence, especially considering the only recent conclusion of the civil war. The conduct of the administrators and even the security arrangements on the actual polling day were praised by observers. IECOM collection of election returns was described by the Carter Center as 'very slow and confused'. However, the Center's quick count mostly around Monrovia on the evening of polling day gave Taylor 62 per cent. A similar process by the UN the next day showed Taylor polling about 75 per cent across the whole country (Carter Center i 997). These estimates are remarkably close to the final result, and suggest that the count, held locally immediately after the close of polling, in the light of day, ratified by all observers, proceeded with few anomalies. Further, it must be noted that any fraud and intimidation on polling day is most likely to have had the greatest effect in remoter areas, the former NPFL heartland, or where there were fewer international and party observers. The three counties of Montserrado, Margibi and Bomi, which are small, immediately accessible to Monrovia, and significantly urbanised, were heavily monitored by independent and party political observers. They also registered 44 per cent of all votes cast. Here, NPP rigging is least plausible, yet Taylor polled 55 per cent, 92 per cent and 86 per cent respectively (6 I per cent over all three areas) in counties that had not been NPFL heartland, and sheltered large numbers of internally displaced people. This is not quite the 75 per cent poll that Taylor achieved over the whole country, but none of these three counties were NPP strongholds. Bong and Nimba counties, core NPFL zones with a large Gio and Mano population, are the second and third most populous counties (a combined 29 per cent of votes cast).

It is not possible to come to an absolute conclusion concerning the free and fair qualities of this election. However, it would seem most likely that a combination of electoral rules, a grossly uneven playing field and a number of irregularities, particularly during the registration period, affected the vote, but hardly enough to transform over 75 per cent into less than $5^{\circ}$ per cent, which would have forced the twocandidate presidential run-off desired by the opposition to Taylor. The winning margin was sufficient to deter even the most vociferous opposition candidates from pursuing their claims of malpractice. Significantly, there were no mass demonstrations or violence after the announcement of the results (Table 2), as had happened, for instance, in Ghana in $199^{2}$ or, more recently, in Lesotho in I 998 . The turnout, 83 per cent of those registered, was high. For whatever reason, the Liberian public had responded to the election and accepted the result. 
TABLE 2

Results of the I 997 Liberian elections; voting for political parties by county (per cent)

\begin{tabular}{|c|c|c|c|c|c|c|c|c|c|c|c|c|c|c|c|}
\hline PPP & $0 \cdot 8$ & $0 \cdot 2$ & 0.4 & $0 \cdot 8$ & 0.7 & $0 \cdot 7$ & $0 \cdot 6$ & $\mathrm{O}^{\cdot} \mathrm{I}$ & 0.5 & $0 \cdot 4$ & $0 \cdot 0$ & $\circ \cdot 6$ & 0.4 & $2, \mathrm{I} 42$ & $0 \cdot 3$ \\
\hline FDP & $0_{4} 4$ & $\mathrm{O} \cdot \mathrm{I}$ & $0 \cdot 2$ & 0.7 & $0 \cdot 3$ & $0 \cdot 4$ & 0.4 & $0 \cdot 2$ & $0 \cdot 3$ & 0.5 & $0^{\circ} \mathrm{O}$ & $0_{4}$ & $0 \cdot 7$ & 2,016 & $0 \cdot 3$ \\
\hline LINU & 0.5 & $\mathrm{O} \cdot \mathrm{I}$ & $O \cdot I$ & 0.4 & $\mathrm{O}^{\circ} \mathrm{I}$ & 0.5 & 5.5 & $\mathrm{O} \cdot 4$ & $0 \cdot 2$ & $\mathrm{I} \cdot 4$ & $0 \cdot 0$ & 0.4 & $0 \cdot 3$ & 6,708 & $I \cdot I$ \\
\hline UP & $4^{\circ} \mathrm{O}$ & $\mathrm{I} \cdot \mathrm{O}$ & $2 \cdot I$ & $7 \cdot 5$ & $\mathrm{I} \cdot 7$ & $2 \cdot 5$ & $2 \cdot 7$ & $4^{\circ} \mathrm{O}$ & $2 \cdot 0$ & $2 \mathrm{I} \cdot 9$ & 0.4 & 4.9 & I 4.4 & 59,557 & $9^{\cdot} 6$ \\
\hline ALCOP & $4 \cdot 7$ & I.9 & I. O & $3 \cdot 6$ & I. & 0.7 & I $7 \cdot 2$ & $\mathrm{I} \cdot 2$ & $\mathrm{I} \cdot 3$ & 4.5 & I.9 & 0.9 & $\mathrm{I}^{\mathrm{T}} \mathrm{T}$ & 25,059 & $4^{\circ} \mathrm{O}$ \\
\hline RAP & $0_{4} 4$ & $0 \cdot 2$ & $0 \cdot 3$ & 0.7 & 0.3 & $0 \cdot 7$ & $0 \cdot 7$ & $0 \cdot 2$ & $0 \cdot 3$ & $0 \cdot 3$ & $\mathrm{O}^{\cdot} \mathrm{I}$ & 0.9 & 0.7 & 2,067 & $0_{3} \cdot 3$ \\
\hline PDPL & $0 \cdot 2$ & $\mathrm{O}^{\circ} \mathrm{O}$ & $\mathrm{O} \cdot \mathrm{I}$ & $0 \cdot 2$ & 0.5 & $9^{\circ} \mathrm{O}$ & $0 * 4$ & $O \cdot I$ & $\mathrm{O} \cdot \mathrm{I}$ & $\mathrm{r} \cdot \mathrm{O}$ & $\mathrm{o} \cdot \mathrm{O}$ & $0 \cdot 3$ & $0 \cdot 4$ & 3,497 & $0 \cdot 6$ \\
\hline UPP & 0.4 & $\mathrm{O} \cdot \mathrm{I}$ & $2 \cdot 3$ & 0.5 & 0.7 & $\mathrm{I} \cdot 2$ & 0.2 & o.9 & $\mathrm{O} \cdot \mathrm{I}$ & $5^{\cdot} \mathrm{I}$ & $O \cdot I$ & го 8 & $8 \cdot 9$ & I 5,604 & $2 \cdot 5$ \\
\hline NDPL & 0.4 & $\mathrm{O} \cdot \mathrm{I}$ & $\mathrm{O} \cdot \mathrm{I}$ & 0.7 & $35^{\prime} \mathrm{I}$ & $\mathrm{O} \cdot 2$ & $0 \cdot 4$ & $\mathrm{O} \cdot \mathrm{I}$ & $\mathrm{O} \cdot \mathrm{I}$ & $1 \cdot 5$ & $\mathrm{o}^{\circ} \mathrm{O}$ & 0.2 & $3^{\cdot 8}$ & 7,843 & $\mathrm{I} \cdot 3$ \\
\hline LPP & $0 \cdot 6$ & $\mathrm{O} \cdot 2$ & $0 \cdot 4$ & $0 \cdot 8$ & $0 \cdot 8$ & $9^{\cdot 6}$ & 0.5 & $\mathrm{O} \cdot \mathrm{I}$ & $0 \cdot 4$ & $3 \cdot 0$ & $\mathrm{O} \cdot \mathrm{I}$ & 0.7 & I0.8 & I0,0I0 & $\mathrm{I} \cdot 6$ \\
\hline Total votes & I 3, O I I & $9^{2,273}$ & $4^{2,562}$ & I 7,384 & $9,73^{2}$ & $8, \mathrm{I} 5^{2}$ & $5^{\mathrm{I}, 943}$ & 33,665 & I 5,506 & $228,25 \mathrm{I}$ & 89,663 & $6,87 \mathrm{I}$ & I 2,867 & 62 г, 880 & гоo \\
\hline
\end{tabular}

Source: Elections Commission, Monrovia. 
THE GANDIDATES AND THE CAMPAIGN

Johnson-Sirleaf and the Unity Party

Johnson-Sirleaf was a very late entry to the presidential race although the UP had existed from before the I985 elections. Her noninvolvement in the war, except a brief period up to mid-rg9o giving support to Taylor from exile, was a mainstay of her campaign message but, at the same time, something that could plausibly count against her at the polls. In one sense, she could put across the image of an untainted, maternal figure, but, in another, she was removed from Liberian politics. While her history of brave opposition to the Doe government was well known, she was also seen as a former minister of the Tolbert government and, despite Gola and Kru ancestry, a member of the old urban elite. In an attempt to combat any notions that she might not have the political strength of a male former warlord, the nickname, 'Iron Lady', was created.

The UP had one of the few well-publicised manifestos in the campaign, which built on Johnson-Sirleaf's considerable experience at the Citibank in Nairobi, the UNDP and the World Bank. She held the post of director of the Regional Bureau for Africa at the UNDP, formulating development strategies for African economies, and was senior loans officer at the World Bank. Campaign strategy focused on redevelopment involving current popular economic ideology such as reduction of government bureaucracy, concentration on the needs of small farmers and the attraction of foreign investment. Johnson-Sirleaf was viewed as the preferred candidate in many Western circles.

\section{Kromah and the All Liberian Coalition Party}

In stark contrast to Johnson-Sirleaf and the UP, the Kromah campaign displayed little substance or political alacrity. Describing himself as 'an apostle of peace' and a 'strong leader', Kromah focused on the possibility of conflict resumption in the event of his defeat. Indeed, it was widely perceived that, along with Taylor, Kromah had maintained stockpiles of weapons and an army in waiting, especially in mineralrich areas contested with ULIMO-J. In February, ECOMOG had found three truckloads of weapons at Kromah's base in Monrovia and placed him temporarily under house arrest (Africa Confidential, 28 Mar. i 997). As late as May I997, a large arms cache was uncovered in former ULIMO-K territory (Agence France Presse, 22 May i 997). 
Kromah's personal image was not helped by the very poor ULIMO$\mathrm{K}$ war record towards civilians, including events as recent as the Sienji massacre in September i996. ULIMO-K and ALCOP were widely perceived as Mandingo entities, and Kromah may well have been distrusted within his own constituency for the deals made with Taylor in the later stages of the war. His rambling, almost royal pronouncements were not impressive. In an interview with West Africa, he stated that, 'we ourselves, as president of the country, will be dealing with the Ministries of Defense, Justice and all the security apparatus, internal affairs as well as foreign affairs, and will sort of give a quasi-primeministerial function to somebody in the government' (West Africa, I 4 July i 997).

\section{The Alliance and others}

The chance of a strong civilian challenge to Taylor may have been lost in the break-up of the original seven-party Alliance, which included the LPP, the UPP, the TWP, the NDPL and the UP. At a convention in late March, the Alliance faltered when the unfavoured Wotorson, a former TWP minister in the Tolbert government, was picked as 'standard-bearer'. Amidst allegations of vote buying, Matthews and Tipoteh withdrew their parties and Johnson-Sirleaf agreed to stand for the UP. The Alliance continued under Wotorson, but its strength had been lost to in-fighting amongst the established political elite, unsurprising when old enemies such as the TWP, the UPP and the NDPL were trying to stand side by side, purely on a platform of opposition to Taylor.

With the exception of Boley, others in the title race had played no part in the war. Repeated appeals were made to the electorate not to vote for 'warlords'. Some could look back on a long history of opposition to authoritarian rule and the UPP and LPP could viably claim to have been strong grassroots parties in the ig8os. A few, such as Matthews and Fahnbulleh, were populists, with considerable charisma. Virtually all, however, suffered from the taint of involvement in the Tolbert and/or Doe administrations, or even the marginalised and ineffectual interim governments. Fahnbulleh, by his own admission, had worked as a security consultant to Kromah during the LNTG period (West Africa, I 4.7. I997). Worse still, Boley was seen as a representative of the Krahn minority and Harry Moniba had been Doe's vice-president. 


\section{Taylor and the National Patriotic Party}

Security played the major role in Taylor's appeals to the electorate. If it wasn't an indirect suggestion that only Taylor could deliver peace, he would make the point that the question of electoral defeat did not arise as it would be impossible for him to lose a free and fair election. Arms caches in former NPFL territory were uncovered by ECOMOG as late as the end of June (IRIN-WA, 6 July r 997). Further, Taylor deliberately used the notion that, having destroyed Liberia, he should be able to apologise and then repair that which was broken.

His message also had populist overtones. Described in one banner as 'Father of the Liberian Revolution' (West Africa, 4 Aug. 1997), Taylor attempted to project the image of a patriot and nationalist. In trying to put himself forward as all things to all men, he claimed Gola and Americo-Liberian ancestry, changed his middle name in I99 I from Macarthur to Ghankay and, with elections looming, added another name, Jarkpana, which is so recent that the author has counted seven different spellings. Taylor became a born-again Christian in late I 996. His campaign has been described as razzmatazz, using Taylor's undoubted charisma, coupled with the doling out of largesse (Africa Confidential, 20 June i 997), particularly rice to replace the hated bulgar wheat distributed by the UN. As he had done with the young fighters in the NPFL, Taylor made massive and totally unrealistic promises. Enoch Dogolea, Taylor's running-mate, promised to transform Butuo, a small town in Nimba County, into a first class city (The Inquirer, i 8 June I 997). The NPP electoral machine was certainly well oiled and well financed but it faced challenges to its image-making. Perceptions of Taylor as a crook, a warlord, a profiteer and the one who was most desperate for the presidency held much currency. Max Sesay (I996: 4Io) describes a popular view of Taylor as a 'congenital liar'. Allegations, such as those from the family of Jackson Doe, still popular amongst the Gio and Mano, that Taylor was responsible for his murder (The Inquirer, 25 June 1997), could have been damaging.

\section{HOW GHARLES TAYLOR WON THE I 997 LIBERIAN ELEGTIONS}

The case for a reassessment of Charles Ghankay Jarkpana Taylor

The election campaign demonstrated that ideology was not an issue, although some journalists have suggested that Liberians' view of Taylor was not quite that of most of the international press (See $\mathcal{N}$ ew African, London, Dec. I997; All-Africa Press Service, Nairobi, 4 Aug. 
I 997). Far from being a brutal warlord, he was seen by many Liberians as the liberator of Liberia from the undoubtedly violent, predatory and deeply unpopular regime of Samuel Doe. It is certainly true that Taylor initiated a multiethnic rebellion against the despised Doe regime. He maintained control over large portions of the country for long periods and established a government in Gbarnga. At certain times, refugees in 'Greater Liberia' received food aid from the NPFL (Brehun I99I: 44). A section of the population in NPFL territory benefitted substantially from NPFL administration, particularly in Nimba County. Stories of NPFL fighters returning to their farms with the spoils of battle emerged very early in the war (Brehun i99 I : 89), and those in the administration would certainly have gained access to the lucrative trade in raw materials.

Taylor's fighters, despite having an appalling record, aimed much of their violence in the early days against Krahns, Mandingos and suspected Doe supporters, groups that had not endeared themselves in recent times to the rest of the population. The NPFL was conceivably better disciplined than ULIMO or LPC, and large core zones of NPFL territory were unaffected by war between i 990 and I994. A farmer in Tubmanburg, a town reduced to rubble in fighting between ULIMO factions, was quoted, 'When Taylor was in charge here I could farm and do whatever I wanted without intimidation' (Reuters, 23 July I 997). Ellis ( I995: г 86) supports this notion in the core zones. It has also been claimed that Taylor could not be held responsible for the actions of all of his fighters, given the circumstances of the initial popular uprising and the later proliferation of factions (Ankomah, New African, Oct. I992).

Against this argument is a catalogue of human rights abuses by unpaid, often very young and traumatised fighters. The NPFL's 'Small Boys Unit' was well known and allegedly used as cannon fodder in the I992 NPFL offensive (HRW/A I994a: 24). Despite accounts of appalling tragedies in zones contested by ULIMO factions (West Africa, I4 Oct. I 996), and severe indictments of LPG behaviour in the south (HRW/A I 994b), most reports specifically point out that all sides were responsible for human rights abuses. Further, to compare abuses by forces seems odious and of little meaning in this context, when there was a wealth of civilian candidates to vote for. NPFL targeting of Krahn and Mandingo in the early stages soon gave way to systematic looting and arbitrary violence, deliberately encouraged as a means of fighter motivation (Outram r997b: 367). Ellis ( 1995: 193) observes that the Poro elements of the violence were purposefully used 
as 'a means of spreading terror and also of psychologically strengthening fighters'. It has been suggested to the author that Taylor would have had over go per cent popularity in early ig9o, but that anyone challenging Doe would have received similar support. ${ }^{14}$

Taylor's government was a controlled commercial empire, within which there is little evidence to support claims of social welfare, beyond international agencies and narrow patronage networks. William Reno ( I993) describes Taylor's 'intensely personalised, almost completely de-institutionalised political networks', and the dearth of anything resembling state functions. The patron-client structures and, particularly, the preference for foreign partners in the exploitation of resources, highlights the continuity in political practices from the Americo-Liberians to Doe to Taylor. The NPFL territory may well have controlled core zones between i 990 and i 994, but even Gbarnga was overrun in the latter year, leaving only northern Nimba County unaffected. Diamond mines fell to ULIMO, timber-rich areas to the LPC, and much of 'Greater Liberia' became contested, with consequent suffering among civilians. Using World Food Programme figures, Quentin Outram estimates that by March i 995 both Bong and Nimba Counties had lost half of their pre-war population, suggesting a far from secure region (i 997a: i93). However, despite his image as a warlord, Taylor was certainly charismatic and eloquent, looked the part of president and ran a well-organised, clever campaign. He had a significant base of popular support in Bong and Nimba Counties, primarily amongst the Gio and Mano, who comprise about i 6 per cent of the Liberian population, and others who benefited from the Taylor regime. The NPP collected over 95 per cent of the vote in both these counties.

\section{The case for feeble opposition}

The opposition to Taylor was singularly unable to unite, much as it was incapable of doing so against Doe in i 985 . Some parallels may be drawn with Kenya's electoral experiences in the iggos (see Throup I 993). If a significant alliance had held, it is conceivable that the total may at least have amounted to more than the sum of the parts, considering that a united front, with international help, would appear more able to confront any actions of Taylor. Individually, the candidates appeared to have either an ethnic or an urban base, only the Unity Party managing any sort of support nationwide. This has particular significance considering that no ethnic group contributes 
more than 20 per cent to the total population (Liebenow r $987: 35) \cdot{ }^{15}$ If the voting was to be significantly influenced by ethnicity, the support of the unrepresented Kpelle and Bassa would be important. However, Boley and Kromah fronted predominantly ethnically based parties, founded on smaller groups, who were ill-disposed with the rest of the population. Both accrued the vast majority of their votes in just two counties, Boley securing nearly go per cent of his total in Grand Gedeh, the Krahn homeland, and Montserrado, with its large numbers of displaced people.

Several others appealed mainly to the urban 'educated' elite, by this time still disproportionately Americo-Liberian, but no longer restricted to this group. Of their total votes, Johnson-Sirleaf and Matthews drew only I 6 and 23 per cent, respectively, from the predominantly rural areas outside Montserrado, where nearly two-thirds of the registered electorate resided. By her own admission, Johnson-Sirleaf had entered the race too late to make significant gains. Another example is Tipoteh, who managed only ro per cent of the vote in Grand Kru and Sinoe, his Kru homeland, and had to rely on two-thirds of his returns materialising in Montserrado. Commentators such as Emmanuel Dolo (I996: I53; see also Malakpa I995) write of 'an anti-intellectual sentiment [that] pervades the Liberian society', and claim that there is a 'blanket accusation that the intellectual community is responsible for everything that has gone wrong in Liberia'. Certainly, the names of several candidates, including Taylor, appear on the lists of previous discredited governments, and Matthews is even, on occasions, blamed for his part in the rice riots that set the conditions for the Doe coup.

The possibility of a successful civilian candidate standing up to Taylor or ensuring security in post-war Liberia was not helped by the personalities available and the previous record of civilians in power. The personalities and their limitations have been discussed. The manipulation of the LNTG chair, Sankawulo, by the heads of warring factions, particularly Taylor, set an ominous precedent, as did the inability of Amos Sawyer to accomplish anything constructive when heading the IGNU. Equally, the indirect threat of a return to war looked particularly impotent in the mouths of former warlords in opposition to Taylor. Boley's faction was small (an estimated 2,500 fighters) and, probably no longer enjoying ECOMOG support, had been rapidly losing territory to the NPFL. The credibility of Kromah's threat was also questionable. Although possessing an estimated 6,800 fighters (of whom 3,507 were disarmed by January 26), ULIMO-K were second-rate players in the war compared to the NPFL (an 
estimated I 2,500 fighters), and controlled smaller, albeit mineral-rich, portions of territory. ${ }^{16}$ The mere fact that Kromah could be arrested speaks volumes. It could, at the same time, be deduced that Kromah's threat to peace was insincere, considering the NPFL/ULIMO-K wartime alliance and the position of Bangalay Fofana, an ULIMO-K stalwart, as minister of commerce in the post-election cabinet.

\section{The case for psychology}

By the time of the election, Taylor had long since adopted the look of a president and it was widely perceived that he would stop at nothing to achieve the actuality. His determination during seven years of conflict, when at times he looked close to total defeat, was self-evident. At the same time, the NPFL was believed to be neither demobilised nor disarmed. UN figures attributed the NPFL with a 54 per cent disarmament rate by January 26 (UNSG i 997). However, in a talk given nearly a month after the formal completion of the demobilisation and disarmament process, Jeremy Armon ( I997) noted the optimistic figures for disarmament, but cautioned that little had been done to disarm the factional leaders themselves, that only 'exceedingly basic' demobilisation had taken place and that private wealth and trade networks remained 'largely unmonitored and unregulated'. As noted above, arms caches in former NPFL territory were uncovered only weeks before the election. A resumption of conflict was a possibility, as had been demonstrated by Jonas Savimbi and UNITA after the observer-verified Angolan elections just five years earlier. Taylor's presidential obsessions appeared uncomfortably reminiscent of Savimbi's. Despite an ECOMOG grasp on the security situation firmer than that of the UN in Angola, Malu's assurances that no force could stand up to the 'peacekeepers' looked far from watertight.

Probably more important, Taylor looked likely to control a deteriorating security situation at the point when the outside world lost what little interest it had managed to muster in Liberia. A resident of Tubmanburg poignantly compared Liberia to neighbouring Sierra Leone "where they put a guy in charge who knows nothing about the gun', referring to the travails of President Ahmed Kabbah (Reuters, 23 July i 997). The turnout, similar to figures for the crucial South African and Mozambican elections and far more than most run-of-the-mill elections worldwide, was high. People were clearly very interested in the conclusion of this election. It could be reasoned that an electorate, in a society mauled by conflict, will turn out in large numbers and have 
security issues uppermost in their minds when approaching the ballot box. Maxwell Owusu ( 1 996: 325) suggests that the mass of Ghanaians who supported Rawlings' proclaimed revolution sought 'effective, realistic and tangible means to cope with misery, hunger, starvation, unemployment and poverty'. In Liberia, the imperatives were similar, but were almost entirely dependent on a reasonably secure environment.

On similar lines, Taylor played on the idea that he was the one to repair the damage caused by the war. A comment often heard went along the lines of 'He who spoil it, let him fix it' (Independent, London, 28 July i 997). This acknowledged, at one and the same time, Taylor's guilt and his ability to atone. Ellis ( 1995: r92) states that 'there can be no doubt that most Liberians have interpreted the violence that has ravaged their country in terms of movements in the spirit world as well as in other terms'. Indeed, Presidents Tubman, Tolbert and Doe all deemed it necessary to have themselves proclaimed supreme authorities of the Poro as a buttress to their power. Some may have seen Taylor as the only one capable of putting the Poro genie back in the bottle, so that these societies may once again play a pacifying role between the spirit and physical worlds. D'Azevedo ( I 969: 9-I I) emphasises the practical application of the secret societies as bases for 'pan-tribal brotherhood' and as 'mechanisms for resolution of conflict'. Although probably partisan, the feeling was summed up by a representative of the Zoes, leaders of Poro societies, whose concern was that 'soldiers saw things they should not have seen and did things they should not have done respective to the "secret bushes" ". He announced that "since [Taylor's] boys destroyed the "bushes", it was only logical to elect him so that he can repair the damage' (Independent Eye, Monrovia, i 8 July i 997).

Finally, Taylor always looked more likely to win than any other candidate. As in Richard Crook's ( I 997) explanation of PDCI success in two Ivorian multi-party elections, Taylor constructed a nationwide coalition from a regional core. The basis of PDCI support lay in patronage and previous reasonably equitable distribution of development projects. Although the security factor underwrote Taylor's coalition, the prospect of development resources probably played a part in his support. In terms of post-election distribution of benefits, it probably seemed better to be inside rather than outside the winning coalition.

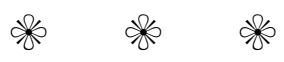

Taylor's overwhelming victory most likely derived from a heady brew 
of electoral rules and irregularities, a huge campaign, a backbone of support, a divided and weak opposition, and his apparent dominance over the security question. It is, though, the latter factor which appears to have been the major determinant of the result. There is clearly a need to treat opposition accusations of electoral fraud in contemporary Africa with caution. Nineties multi-party elections are often fairer and freer than in previous decades. The 1985 Liberian election differs strikingly from most nineties African polls in that there were no international observers and that the count was so blatantly fabricated. The Ugandan elections of I 980 are another example. Today, in an era when international financial institutions hold the purse strings and employ political conditionalities in some form or other, a degree of respectability is required. In Liberia's case, it was not only the NPP who required the elections to look respectable, but also the Nigerian regime in its own search for international legitimacy. Unlevel playing fields will also continue to be a bone of contention and are unlikely to disappear in the near future. Jan Kees van Donge ( $1998: 98$ ) has called for 'the need for relative rather than absolute judgements of elections'. Some will see this as a slippery slope. However, an equally dangerous path is that which allows every election to be potentially devalued by losing candidates' allegations that are sometimes little more than that.

Liberians probably voted for the candidate who was most likely to enforce security and offer the best chance of improving their living conditions. It must be acknowledged that a large proportion of the electorate seemed not to be deflected by the gross human rights abuses of the NPFL or the evidence of authoritarianism in Taylor's war-time regime. That said, Liberians voted en masse against the brutal Doe regime, but there were significant economic factors at play there as well. In Ghana, in I992, it is possible that many rural people chose Jerry Rawlings because their lot was improved, overlooking the extensive human rights abuses of the regime during the eighties (Jeffries \& Thomas I 993). Renamo, with its abysmal record of abuses, managed respectable electoral results in Mozambique in i 994, especially in rural areas where Frelimo economic policy had neglected small farmers (see Vines I 996). In two of the few examples of incumbent defeat in Africa, Kenneth Kaunda and Manuel Pinto da Costa led not particularly repressive regimes, but lost the i 99 I elections in Zambia and São Tomé e Príncipe, due largely to ruined economies (for Zambia, see Bratton I 994; for São Tomé, Chabal r 996). ${ }^{17}$

Even in the light of these other recent examples, some outside observers of the Liberian case did not take into account what appear 
to be often overriding economic concerns of many African electorates. Describing Taylor as 'the single-most person responsible for the nation's tragedy' and as a 'figure of contempt in some parts of Liberia' (Washington Post, 23 July i 997) hardly paints a useful or even accurate picture. At the same time, other portrayals of Taylor as a liberator of the Liberian people appear to be equally misleading. Liberians, in all probability, were looking for a betterment of their economic status in a stable environment. The fear that Taylor's exclusion from the Executive Mansion would deliver quite the opposite weighed heavily on the outcome. It remains to be seen whether the election has conferred on Taylor any legitimacy or longevity in power.

\section{NOTES}

I For the help of the reader each presidential candidate in the r 997 election is presented in bold as they first appear in the text. Tipoteh was budget advisor to the government. Boley was a member of a TWP think tank. Johnson-Sirleaf's position as finance minister is well documented.

2 Africa Confidential (London I997, I4) described Taylor as 'the first Plymouth escapee in recent memory to have avoided recapture' and rumours of CIA complicity in his escape have passed around.

3 Estimates vary between 250 (Lowenkopf r 995: 92) and roo (Ellis i 995: i66). Most agree, however, that there was a strong contingent of non-Liberians, particularly Burkinabé.

4 Reno (I996a: го), however, estimates a much larger income of US\$400-450 million p.a.

5 Outram (I 997: I 93) estimates from various sources 700,00o Internally Displaced People

(IDP) and 727,00o refugees in October i 995. However, his figure for IDPs is as high as I 2 million in $\mathrm{I} 99 \mathrm{I}$.

6 Taylor's inaugural speech singled out Abacha for special mention. Abacha, in turn, described Taylor's inauguration as 'epic-making'.

7 Star Radio, funded by a Swiss NGO, began broadcasting to the whole country, but only two days before the polls.

8 Various figures are available for refugees outside Liberia. Tanner (I998: I39) estimates $5^{\mathrm{Oo}, 000}$ and states that only Io-20 per cent of the eligible refugee population in Côte d'Ivoire and Guinea returned to vote. UNHCR estimates put the figure at 660 ,ooo with sporadic returns (UNSG, I9 June I997).

9 To date, the document has not appeared.

io For example, the eye-witness account related to the author. Also, Emmanuel D. Howe in First National Poll (Monrovia, 30 June i 997).

I I The author's discussions with a presidential candidate in July r 998 revealed several unsubstantiated conspiracies including the manufacture of alterable voting cards in Accra with Libyan money. The death of IECOM head, G. Henry Andrews, of heart failure on 3 September I 997 is seen as far too convenient by some.

I 2 'Only angels from heaven [would] save G. Henry Andrews if the July igth elections were to be postponed' (Monrovia Daily News, I 7 July i 997).

I 3 Major-General Malu's response, 'If you stone we will bullet' (The Inquirer, 25 June i 997).

I 4 Thanks must go to Max Bankole Jarrett at the BBC World Service for this point.

I 5 The largest groups are the Kpelle and the Bassa (20 per cent and I $4 \%$ ). More politically prominent groups, such as the Krahn, Mandingo, Gio and Mano are smaller (5 per cent, 4 per cent, 9 per cent \& 7 per cent, respectively).

I6 UN revised estimated faction strengths and disarmament figures as of 26 January I 997 (UNSG, 29 Jan. I 997). The total number of disarmed fighters (I 2,5 I0) at this date is, however, only 59 per cent of the total figure (2 I,3 I 5) given without a breakdown in June (UNSG, I9 June I 997 ). 
I 7 In the latter case, Pinto da Costa's party lost the election but he withdrew from the presidential race before he could follow suit.

\section{REFERE N GES}

Africa Watch. I990a. 'Liberia: flight from terror: testimony of abuses in Nimba County', reprinted in Liberian Studies fournal I 5, I : I 42-6 I.

Africa Watch. I99ob. 'Liberia: a human rights disaster', reprinted in Liberian Studies Fournal i6, I : $129-55$.

Africa Watch. i99I. 'Liberia: the cycle of abuse', reprinted in Liberian Studies Fournal i 7, i: I $28-64$.

Armon, J. I997. 'Talk at the FCO African Research Group'. London: Conciliation Resources, 4 March.

Berkeley, B. I986. Liberia: a promise betrayed. New York: Lawyers Committee for Human Rights.

Bratton, M. I 994. 'Economic crisis and political realignment in Zambia', in J. Widner, ed., Economic Change and Political Liberalisation in Sub-Saharan Africa. Baltimore: Johns Hopkins University Press.

Brehun, L. I99I. Liberia: the war of horror. Accra: Adwinsa.

Carter Center. I997. Liberia Trip Report, www.emory.edu/CARTER_CENTER, 4 August.

Chabal, P. I996. 'The prospects for democracy in Lusophone Africa', Portuguese Studies I 2: I $85^{-200 .}$

Clapham, C. I989. 'Liberia', in D. Cruise O'Brien et al., eds., Contemporary West African States. Cambridge University Press.

Crook, R. I997. 'Winning coalitions and ethno-regional politics: the failure of the opposition in the r 990 and r 995 Elections in Côte d'Ivoire', African Affairs 96, 383: 2 I 5-42.

D'Azevedo, W. i 969, i 970-I. 'A tribal reaction to politics (Part I)', Liberian Studies fournal I, 2 : I-2 I ; (Part 4), Liberian Studies fournal 3, I : I-I 9.

Dolo, E. i 996. Democracy vs. Dictatorship. Maryland: University Press of America.

Ellis, S. I 995. 'Liberia I989-94: a study of ethnic and spiritual violence', African Affairs 94, 375: I $65-97$.

Foreign and Commonwealth Office (FCO) contribution to EU election monitoring. I 997. Report by the Electoral Reform International Services. London: FCO. July.

Friends of Liberia (FOL). ig97a. Testimony to the House Subcommittee on Africa. Washington: FOL. 24 June.

FOL. I 997b. Liberia's Special Elections, Preliminary Statement of Findings. Virginia: FOL. 23 July.

FOL. I997c. Observation of the 1997 Election, Liberia, Final Report and Evaluation. Virginia: FOL. September.

Huband, M. I998. The Liberian Civil War. Ilford: Frank Cass.

Human Rights Watch/Africa (HRW/A). I 994a. Easy Prey: child soldiers in Liberia. New York: HRW/A.

HRW/A. I 994b. 'Human rights abuses by the LPG and the need for international oversight', reprinted in Liberian Studies Fournal, 20, I : I62-7 I. I 7 May.

Jeffries, R. I 998. 'The Ghanaian elections of i 996 : towards the consolidation of democracy?', African Affairs 97, 387: 189-208.

Jeffries, R. \& C. Thomas, i 993. 'The Ghanaian elections of I 992', African Affairs 92, 368: 33 I-66.

Kees van Donge, J. I 998. 'Reflections on donors, opposition and popular will in the I996 Zambian General Elections', Journal of Modern African Studies 36, I : 7 I-99.

Konneh, A. I996. Religion, Commerce and the Integration of the Mandingo in Liberia. Maryland: University Press of America.

Lawyers Committee for Human Rights (LCHR). i 990. 'Critique of the US Department of State Review of Human Rights in Liberia', reprinted in Liberian Studies Fournal, I6, 2: I o8-I I.

Liebenow, J. I987. Liberia: the quest for democracy. Bloomington: University of Indiana Press.

Lowenkopf, M. i 995. 'Liberia: putting the state back together', in I. W. Zartman. Collapsed States. Boulder, CO: Lynne Rienner.

Lyons, T. I999. Voting for Peace: postconflict elections in Liberia. Washington: Brookings Institution Press.

Malakpa, S. i 995. 'Anti-intellectualism: a virulent impediment to socio-economic development - Africa's experience, Liberia's lesson', Liberian Studies fournal 20, I : 37-47. 
Ogunleye, B. 1995. Behind Rebel Line: anatomy of Charles Taylor's hostage camps. Enugu: Delta Publications.

Osaghae, E. I996. Ethnicity, Class and the Struggle for State Power in Liberia. Dakar: CODESRIA.

Outram, Q. r 997a. 'Cruel wars and safe havens: humanitarian aid in Liberia i 989-96', Disasters 21, 3: 189-203.

Outram, Q. 1997b. 'It's terminal either way: an analysis of armed conflict in Liberia: 1989-96', Review of African Political Economy 24, 73: 355-71.

Owusu, M. I996. 'Tradition and transformation: democracy and the politics of popular power in Ghana', Fournal of Modern African Studies 34, 2: 307-43.

Reno, W. I993. 'Foreign firms and the financing of Charles Taylor's NPFL', Liberian Studies fournal i 8, 2: I 75-88.

Reno, W. I996a. 'Humanitarian emergencies and warlord politics in Liberia and Sierra Leone'. Helsinki: paper presented to the United Nations University/ WIDER conference.

Reno, W. I 996b. 'The business of war in Liberia', Current History 95, 60 I : 2 I I-I 5.

Sesay, M. 1996. 'Politics and society in post-war Liberia', Journal of Modern African Studies 34, 3: 395-420.

Tanner, V. 1998. 'Liberia: railroading peace', Review of African Political Economy 25, 75: 133-47.

Tipoteh, T. I98I. Democracy: the call of the Liberian people. Monrovia: SUSUKUU.

Throup, D. I993. 'Elections and political legitimacy in Kenya', Africa 63, 3: 37 I-96.

United Nations Department of Humanitarian Affairs, Integrated Regional Information Network for West Africa (IRIN-WA) (I997). Weekly Roundups. Abidjan, available through e-mail, irinwa@africaonline.co.ci.

United Nations Security Council (UNSC). 30 July i 997. Press Release. New York: UNSC.

UNSG. 2 I January 1997a. $21^{\text {st }}$ Progress Report of the Secretary-General on the UN Observer Mission in Liberia, www.un.org/Docs/sc/reports/ I 997/si $99790 . h t m$

UNSG. I9 June 1997b. $23^{\text {rd }}$ Progress Report of the Secretary-General on the UN Observer Mission in Liberia, www.un.org/Docs/sc/reports/I 997/si $997478 . h t m$

Vines, A. 1996. Renamo: from terrorism to democracy in Mozambique? York: Centre for Southern Africa Studies.

World Bank. Atlas. i995. Washington: World Bank. 